\title{
Pengaruh Perubahan Penggunaan Lahan terhadap Volume Runoff di Kawasan Perkotaan Yogyakarta Tahun $2008-2018$
}

\author{
Isham Jibran, Sola Tri Astuti, Fitria Nucifera
}

Masuk: 22102021 / Diterima: 23112021 / Dipublikasi: 01122021

\begin{abstract}
Yogyakarta Urban Area covers the entire area of Yogyakarta City and part of Sleman Regency and Bantul Regency. Every year land use changes, especially in Yogyakarta Urban Area, accompanied by changes in rainfall intensity. This study focuses on the relationship between land use change and runoff volume. Land use changes were classified using the unsupervised method based on Landsat 5 and 8 images with 5-year intervals (2008, 2013, and 2018). The maximum runoff volume is calculated using the SCS-CN method. The relationship between two results was analyzed using the Pearson correlation method. The results showed that during 2008 - 2018 the area of built-up land increased by 19.5\% from 11,755.6 ha in 2008 to $14,059.5$ ha in 2018. The runoff volume increased by $76.6 \%$ from $7,268.68 \mathrm{~m}^{3}$ in 2008 to $12,837.63 \mathrm{~m}^{3}$ in 2018 . This is evidenced by the high significance of the correlation value below $5 \%$ with $t$-count greater than $t$-table. The $Y$ correlation shows that if the built-up area increased by 100 ha, there will be an increase runoff volume of $76.09 \mathrm{~m}^{3}$. Y correlation for open land if increases by 100 ha, there is an increase runoff volume of $59.27 \mathrm{~m}^{3}$. On vegetation land, if the vegetated land increased by 100 ha, the runoff volume will increase by $54 \mathrm{~m}^{3}$. This shows that the wider use of built-up land, make the larger runoff volume.
\end{abstract}

Key words: Land Use; Runoff Volume; Yogyakarta Urban Area

\begin{abstract}
Abstrak Kawasan Perkotaan Yogyakarta mencakup seluruh wilayah Kota Yogyakarta dan sebagian Kabupaten Sleman serta Bantul. Setiap tahunnya penggunaan lahan mengalami perubahan terutama pada Kawasan Perkotaan Yogyakarta, disertai dengan perubahan intensitas hujan. Penelitian ini berfokus pada hubungan perubahan penggunaan lahan dengan volume runoff. Perubahan penggunaan lahan diklasifikasikan menggunakan metode unsupervised berdasarkan citra Landsat 5 dan 8 dengan interval 5 tahunan (2008, 2013, dan 2018). Volume runoff maksimum dikalkulasi menggunakan metode SCS-CN. Hubungan kedua hasil tersebut dianalisis dengan metode korelasi Pearson. Hasil penelitian menunjukkan bahwa selama tahun 2008 - 2018 luas lahan terbangun meningkat sebanyak 19,5\% dari 11.755,6 ha pada tahun 2008 menjadi $14.059,5$ ha pada tahun 2018. Volume runoff mengalami peningkatan sebanyak 76,6\% dari 7.268,68 $\mathrm{m}^{3}$ pada tahun 2008 menjadi $12.837,63 \mathrm{~m}^{3}$ pada tahun 2018 . Hal tersebut dibuktikan dengan tingginya signifikansi hasil nilai korelasi dibawah $5 \%$ dengan $\mathrm{t}-$ hitung lebih besar dari t-tabel. Korelasi Y menunjukkan jika lahan terbangun bertambah 100 ha maka terdapat kenaikan volume runoff sebanyak $76.09 \mathrm{~m}^{3}$. Korelasi $\mathrm{Y}$ untuk lahan terbuka jika bertambah 100 ha maka terdapat kenaikan volume runoff sebanyak $59.27 \mathrm{~m}^{3}$. Pada lahan vegetasi, jika luas lahan vegetasi bertambah 100 ha, volume runoff akan bertambah $54 \mathrm{~m}^{3}$. Hal ini menunjukkan bahwa semakin luas penggunaan lahan terbangun maka volume runoff juga semakin besar.
\end{abstract}

Kata kunci: Penggunaan Lahan; Volume Runoff; Kawasan Perkotaan Yogyakarta

This is an open access article under the CC BY-SA license.

Copyright @ 2021 by Author. Published by Universitas Pendidikan

Ganesha.

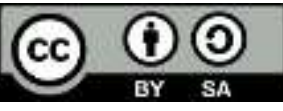




\section{Pendahuluan}

Proses urbanisasi tidak dapat dihindarkan dari perkembangan kehidupan manusia saat ini. Pada beberapa dekade terakhir telah terjadi percepatan laju urbanisasi terutama di negara berkembang (Chadchan \& Shankar, 2009). Sebanyak $64 \%$ negara berkembang di dunia diprediksikan akan mengalami urbanisasi pada tahun 2050 (United Nations Department of Economic and Social Affairs, 2015).

Urbanisasi memberikan dampak baik dan buruk. Pada proses urbanisasi terjadi transformasi dari lahan nonterbangun menjadi lahan terbangun sehingga berdampak pada kondisi fisik lahan (Patra et al., 2018). Perubahan penggunaan lahan yang terjadi akibat urbanisasi mengakibatkan berkurangnya tutupan vegetasi sehingga memicu peningkatan suhu permukaan, polusi udara, tingginya variabilitas hujan, peningkatan volume runoff, serta terganggunya neraca air (Liu Jianguo, 2005; Zhou et al., 2017).

Dampak hidrologi akibat perubahan penggunaan lahan di perkotaan merupakan permasalahan serius. Penambahan luas area kedap air di perkotaan berdampak pada penurunan kapasitas lahan dalam meresapkan air sehingga berakibat pada kenaikan volume runoff ( $\mathrm{He}$ et al., 2013). Penilaian pengaruh urbanisasi terhadap volume runoff penting dilakukan untuk perencanaan perkotaan dan manajemen bencana khususnya banjir (Hu et al., 2020)

Kawasan perkotaan di Indonesia berkembang secara masif pada

Isham Jibran ${ }^{1}$, Sola Tri Astuti ${ }^{1}$, Fitria Nucifera ${ }^{1}$,

${ }^{1}$ Universitas AMIKOM Yogyakarta, Indonesia

fnucifera@amikom.ac.id beberapa dekade terakhir. Percepatan laju urbanisasi telah terjadi pada 21 propinsi di Indonesia pada tahun 2005, bahkan 10 propinsi mengalami laju urbanisasi lebih dari $40 \%$ termasuk diantara propinsi Daerah Istimewa Yogyakarta (Wilonoyudho et al., 2017). Oleh karena itu, propinsi Daerah Istimewa Yogyakarta membutuhkan perhatian khusus dalam hal perubahan penggunaan lahan yang berkaitan dengan volume runoff.

Pusat lahan terbangun di Propinsi Daerah Istimewa Yogyakarta terletak di Kawasan Perkotaan Yogyakarta. Menurut PERDA Provinsi DIY NO. 2 Tahun 2010, Kawasan Perkotaan Yogyakarta (KPY) merupakan penggabungan dari sebagian wilayah Kabupaten Sleman dan Bantul serta keseluruhan wilayah Kota Yogyakarta. Wilayah - wilayah tersebut memiliki berbagai jenis penggunaan lahan dengan berbagai fungsi. Berbagai penggunaan lahan memiliki respon yang berbeda terhadap hujan yang jatuh sehingga akan berdampak pada volume runoff (Sajikumar \& Remya, 2015). Perubahan pada penggunaan lahan secara langsung akan berdampak pada perubahan runoff (Shang et al., 2019). Metode SCS-CN merupakan salah satu metode yang umum digunakan untuk menghitung estimasi runoff. SCS-CN mempertimbangkan karakteristik lahan seperti karakteristik tanah, lereng, vegetasi dan penggunaan lahan (United States Department of Agriculture, 1986). Metode ini telah banyak digunakan untuk berbagai kajian mengenai runoff antara lain dampak penggunaan lahan terhadap runoff (He et al., 2013; Psomiadis et al., 2020) dan pengaruh 
kelerengan terhadap runoff (Mishra et al., 2014).

Penelitian ini berfokus pada identifikasi spasial dan temporal perubahan penggunaan lahan serta estimasi volume runoff menggunakan metode SCS-CN dalam kurun waktu tahun 2008 hingga 2018. Integrasi penginderaan jauh dan SIG diterapkan dalam penelitian ini untuk mengetahui hubungan antara perubahan penggunaan lahan dengan perubahan volume runoff. Penelitian ini memberikan kontribusi terhadap kajian hidrologi perkotaan khususnya pada perkotaan yang mengalami percepatan laju urbanisasi.

\section{Metode}

Penelitian ini berfokus pada hubungan antara perubahan penggunaan lahan dengan volume runoff. Rincian perolehan data dan fungsi data yang digunakan dalam penelitian terdapat pada Tabel 1. Tahapan penelitian meliputi pengumpulan data, pengolahan data, dan analisis. tersaji pada Gambar 1.

Tabel 1. Perolehan dan Fungsi Data

\begin{tabular}{|c|c|c|c|}
\hline Jenis Data & Tahun & Sumber Data & Fungsi Data \\
\hline Citra Landsat 5 & 2008 & USGS & Klasifikasi Penggunaan Lahan \\
\hline Citra Landsat 8 & $2013 \& 2018$ & USGS & Klasifikasi Penggunaan Lahan \\
\hline SRTM Yogyakarta & - & USGS & Pembuatan Hillshade \& Kontur \\
\hline $\begin{array}{l}\text { Curah hujan wilayah per } \\
\text { jam }\end{array}$ & $\begin{array}{l}2008,2013 \\
\& 2018\end{array}$ & BBWS & $\begin{array}{l}\text { Penentuan pembagian hujan } \\
\text { wilayah dan Perhiyungan SCS- } \\
\text { CN }\end{array}$ \\
\hline \multicolumn{4}{|l|}{ Shape file: } \\
\hline $\begin{array}{l}\text { Kawasan Perkotaan } \\
\text { Yogyakarta }\end{array}$ & 2019 & $\begin{array}{l}\text { Dinas Pertanahan dan } \\
\text { Tata Ruang Daerah } \\
\text { Istimewa Yogyakarta }\end{array}$ & Penentuan AOI \\
\hline $\begin{array}{l}\text { Daerah Istimewa } \\
\text { Yogyakarta }\end{array}$ & - & $\begin{array}{l}\text { BIG / Indonesia } \\
\text { Geospatial Portal }\end{array}$ & Pembuatan Peta Administrasi \\
\hline
\end{tabular}

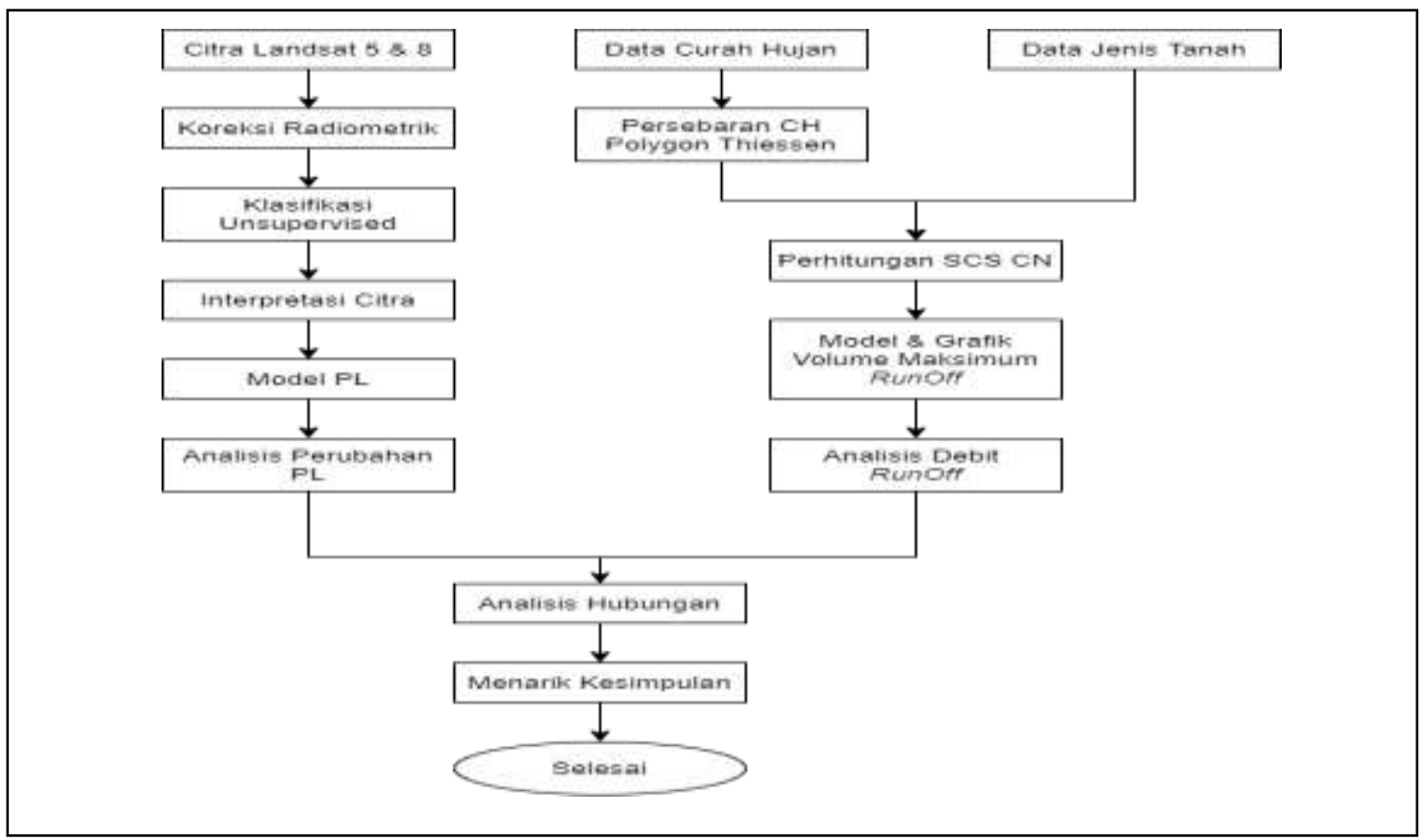

Gambar 1. Tahapan penelitian

233 | Media Komunikasi Geografi, Vol. 22, No. 2, Desember 2021: 231-246 


\section{Pengolahan Data}

Tahap pengolahan data meliputi koreksi radiometrik Citra Landsat 5 dan 8, serta klasifikasi penggunaan lahan dengan metode unsupervised. Data curah hujan yang digunakan didasarkan pada dekatnya stasiun hujan terhadap Kawasan Perkotaan

Yogyakarta. Pengolahan data hujan menggunakan metode Polygon

Thiessen untuk mengetahui persebaran curah hujan. Stasiun hujan yang digunakan yaitu stasiun hujan

Pajangan, Karang Ploso, Bedukan, Nyemengan, Beran, Tanjung Tirto, Santan, Prumpung, Plataran, Gemawang, dan Godean.Perhitungan runoff menggunakan metode SCS-CN (Soil Conservation Service Curve Number) yang didasarkan pada persamaan neraca air dan terdapat dua hipotesis dasar. Pertama dengan menyamakan rasio aliran air permukaan langsung $(Q)$ terhadap total curah hujan atau potensi tebal runoff maksimum $(P)$ dengan rasio jumlah infiltrasi sebenarnya $(F)$ dengan potensi maksimal ketahanan tanah atau retensi air (S). Hipotesis kedua yaitu menghubungkan abstraksi awal (la) dengan potensi retensi maksimum. Perhitungan volume maksimum runoff pada analisis ini menggunakan metode SCS-CN dengan rumus sebagai berikut (United States Department of Agriculture, 1986):

$Q=\frac{\left(P-l_{a}\right)^{2}}{(P-h)+}$

$Q=$ Tebal Runoff (mm)

$I_{a}=$ Abstraksi awal (Initial Abstraction)

$P=$ Hujan harian $(\mathrm{mm})$

$S=$ Volume dari total simpanan permukaan (retention parameter) (mm)
Pada abstraksi awal, hal tersebut termasuk pada vegetasi, depression storage (simpanan air yang disebabkan oleh kubangan/cekungan), evaporasi, dan infiltrasi. Hal - hal tersebut penting adanya sebelum terjadi runoff. Nilai dasar dari abstraksi awal tersebut diberi dengan perhitugan berikut:

$$
I_{a}=0.2 \mathrm{~S}
$$

Perhitungan tersebut dapat di sederhanakan menjadi tiga varabel saja seperti berikut:

$Q=\frac{(P-0.2 S)^{2}}{(P+0.8 S)}$

Untuk menyederhanakan perhitungan kelembapan awal (antecedent moisture condition), penggunaan lahan dan konservasi tanah/tutupan vegetasi, US SCS menentukan besar $S$ sebagai berikut:

$$
\begin{aligned}
& S=25.4 \frac{100}{C N}-10 \\
& S=\frac{25400}{C N}-254
\end{aligned}
$$

Adanya runoff dipengaruhi oleh hujan $(P)$ yang lebih besar dibandingkan dengan abstraksi awal $\left(I_{a}\right)$. Faktor yang penting dalam menentukan $\mathrm{CN}$ adalah hydrologic soil group (HSG) atau kelompok tanah hidrologi, jenis tutupan, treatment, kondisi hidrologi, dan kondisi runoff anteseden atau antecedent runoff condition (ARC). Faktor lainnya yang dapat dipertimbangkan yaitu apakah daerah yang tidak dapat menyerap air langsung terhubung dengan sistem drainase atau apakah aliran air menyebar pada area sebelumnya sebelum memasuki sistem drainase (tidak terkoneksi).

Volume laju runoff dipengaruhi oleh kondisi kelembapan tanah awal atau 
Anteccedent Moisture Condistion (AMC). Dari hal tersebut, maka terdapat tiga susunan kondisi kelembapan tanah berdasarkan jumlah hujan selama 5 hari yang dibuat oleh Soil Conservation Service (SCS) (Triatmojo, 2010):

1. AMC I (Antecedent Moisture Condition I) merupakan analisa kondisi yang digunakan pada bulan kering atau kemarau. Kondisi ini menjelaskan tanah DAS dalam keadaan kering, runoff rendah, namun tidak mencapai titik layu, telah atau pernah ditanami dengan tanaman dengan hasil baik.

2. AMC II (Antecedeng Moisture Condition II) merupakan analisa kondisi yang mendeskripsikan kondisi tanah berada pada keadaan rata - rata atau average condition.

3. AMC III (Antecedent Moisture Condition III) merupakan analisa kondisi yang digunakan pada bulan basah atau musim hujan. Kondisi ini dideskripsikan dengan adanya hujan lebat atau ringan dan suhu temperatur yang rendha, tanah DAS jenuh air, dan runoff tinggi.

Kedua kondisi $\mathrm{AMC}$ tersebut $\left(\mathrm{AMC}_{\mathrm{I}}\right.$ dan $\mathrm{AMC}_{\text {III) }}$ sejalan engan $\mathrm{CN}$ atau Curve Number dan dapat dikalkulasi dengan perhitungan berikut (Triatmojo, 2010):

$$
\begin{gathered}
C N_{I}=\frac{4.2 C N_{\| l}}{10-0.058 C N_{l}} \\
C N_{I I I}=\frac{23 C N_{\|}}{10-0.13 C N_{\| l}}
\end{gathered}
$$

Setelah dilakukan perhitungan SCS $\mathrm{CN}$ maka langkah selanjutnya yaitu menghitung volume maksimum dengan mengalikan luas area (acre) per poligon Thiessen yang telah dibuat dan digabungkan dengan data jenis tanah, $\mathrm{CH}$, dan SCS-CN dengan nilai $\mathrm{Q}$ yang telah dikonversi menjadi ft. Setelah dikalikan kemudian dikonversi lagi ke $\mathrm{ft}^{3}$ lalu $\mathrm{m}^{3}$ dan dibuat model serta grafiknya pada setiap tahun yang diteliti.

Sementara untuk membandingkan penggunaan lahan pada tahun 2008, 2013, dan 2018 menggunakan metode unsupervised dan citra landsat 5 serta 8. Hasil model dan grafik tersebut kemudian akan dianalisis korelasinya dengan metode analisis korelasi pearson dan akan dihubungkan dengan analisis perubahan penggunaan lahan. Analisis data diwujudkan dengan grafik linear hubungan antara penggunaan lahan dengan volume runoff. Korelasi pearson dinilai berdasarkan koefisien korelasi $\left(\boldsymbol{r}_{x y}\right)$ yang berada pada nilai -1 $<0<1$ yang dimana pabila $r=-1$ maka korelasi tersebut merupakan korelasi negatif sempurna yang menyatakan bahwa taraf signifikansi dari variable $X$ terhadap variable $Y$ sangat lemah. Jika $r=1$ maka korelasi relatif tersebut memiliki korelasi positif sempurna yang menandakan taraf signifikansi variable $X$ terhadap variable $Y$ sangat kuat (Sugiyono, 2006). Jika koefisien berada di angka 0 maka tidak adanya hubungan antara dua variable tersebut. Rumus 6 adalah rumus korelasi pearson:

$$
\begin{aligned}
& r_{x y}
\end{aligned}
$$

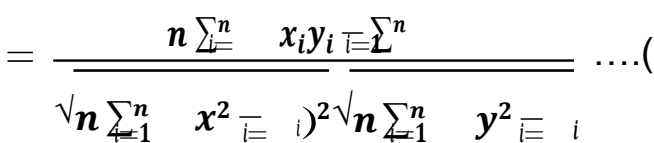

$$
\begin{aligned}
& \sum_{\mathrm{i}=1}^{\mathrm{n}} x_{i}=\text { Jumlah data } x_{i} \\
& \sum_{\mathrm{n}=1}^{\mathrm{n}} y_{i}=\text { Jumlah data } y_{i} \\
& \sum_{\mathrm{n}}^{\mathrm{i}=1} x_{x y_{i}}^{y_{i}} \quad \text { Jumlah data } x \text { dan } y_{i} \\
& \sum^{\mathrm{n}=1} x^{I^{2}} \quad=\text { Jumlah dari } x^{i} \\
& \sum_{\mathrm{i}=1}^{\mathrm{n}=1} y_{i}^{i_{2}} \quad=\text { Jumlah dari } y_{i}^{i_{2}}
\end{aligned}
$$




$$
\begin{aligned}
& n \quad=\text { Banyak sample } \\
& r \quad=\text { Koefisien korelasi } \\
& x \quad=\text { Variabel independen } \\
& y=\text { Variabel dependen }
\end{aligned}
$$

Hasil analisis tersebut akan dilakukan uji hipotesis korelasi dengan menggunakan tingkat kesalahan 5\% (0.05) atau tingkatan kepercayaan sebanyak $95 \%$ dengan menggunakan uji hipotesis two-tail serta beberapa kriteria. Pengujian hipotesis menggunakan Uji-T sebagai penguji hipotesis korelasi koefisen dengan tingkat kesalahan 5\% (Rumus 7). Hal ini dilakukan untuk mengetahui apakah variabel penggunaan lahan dengan volume runoff memiliki hubungan atau korelasi secara signifikan setiap tahunnya (Sugiyono, 2006). Pengujian $P$ - value dilakukan dengan menghitung luasan daerah di bawah kurva normal. Perhitungan tersebut dilakukan pada excel.

$\mathrm{H}_{0}: \rho=0$ (Tidak memiliki hubungan antara variabel $\mathrm{X}$ dan $\mathrm{Y}$ )

$\mathrm{H}_{1}: \rho \neq 0$ (Adanya hubungan antara variabel $X$ dan $Y$ )

$t=\frac{r \times \sqrt{n-2}}{\sqrt{1-r^{2}}}$

$t=$ Nilai $\mathrm{t}$-hitung

$r=$ Koefisien Korelasi

$n=$ Jumlah data pengamatan

$\mathrm{H}_{0}$ diterima 0 jika $t_{\text {hitung }}<\mathrm{t}_{\text {tabel }}$ atau nilai

sig. (Probabilitas) $>0.05$
$\mathrm{H}_{0}$ dtiolak 0 jika $t_{\text {hitung }}>\mathrm{t}_{\text {tabel }}$ atau nilai sig. (Probabilitas) $<0.05$

\section{Hasil dan Pembahasan}

$\begin{array}{lll}\text { Distribusi } \quad \text { Spasial } & \text { Temporal } \\ \text { Penggunaan Lahan di } & \text { Kawasan } \\ \text { Perkotaan Yogyakarta } & & \end{array}$

Penggunaan lahan di Kawasan

Perkotaan Yogyakarta mengalami peningkatan yang tidak terlalu signifikan dari tahun ke tahun. Hal tersebut tetap berpengaruh terhadap keadaan lingkungan dalam menampung volume runoff terutama saat intensitas hujan tinggi. Penggunaan lahan pada penelitian ini didasarkan oleh tutupan lahan dari tahun 2008, 2013 dan 2018. Pada Gambar 2 terdapat perubahan secara spasial terutama pada jenis penggunaan lahan pemukiman dengan luas $1 / 8$ acre $(0,05 \mathrm{ha})$ dan $1 / 4$ acre $(0,1$ ha). Lahan vegetasi mengalami perubahan menjadi beberapa lahan terbangun yaitu lahan komersial yang terkonsentrasi pada sekitar lahan vegetasi dekat dengan jalan, dan lahan pemukiman 0,05 ha serta 0,1 ha pada area sawah atau terkonsentrasi pada area pinggiran kota. Setiap tahunnya pemukiman 0,05 ha mengalami pertumbuhan, terlihat jelas dengan warna coklat tua muncul pada daerah pinggiran Kota Yogyakarta, yaitu pada Kecamatan Kasihan, Mlati, Sewon, Banguntapan dan Depok. 


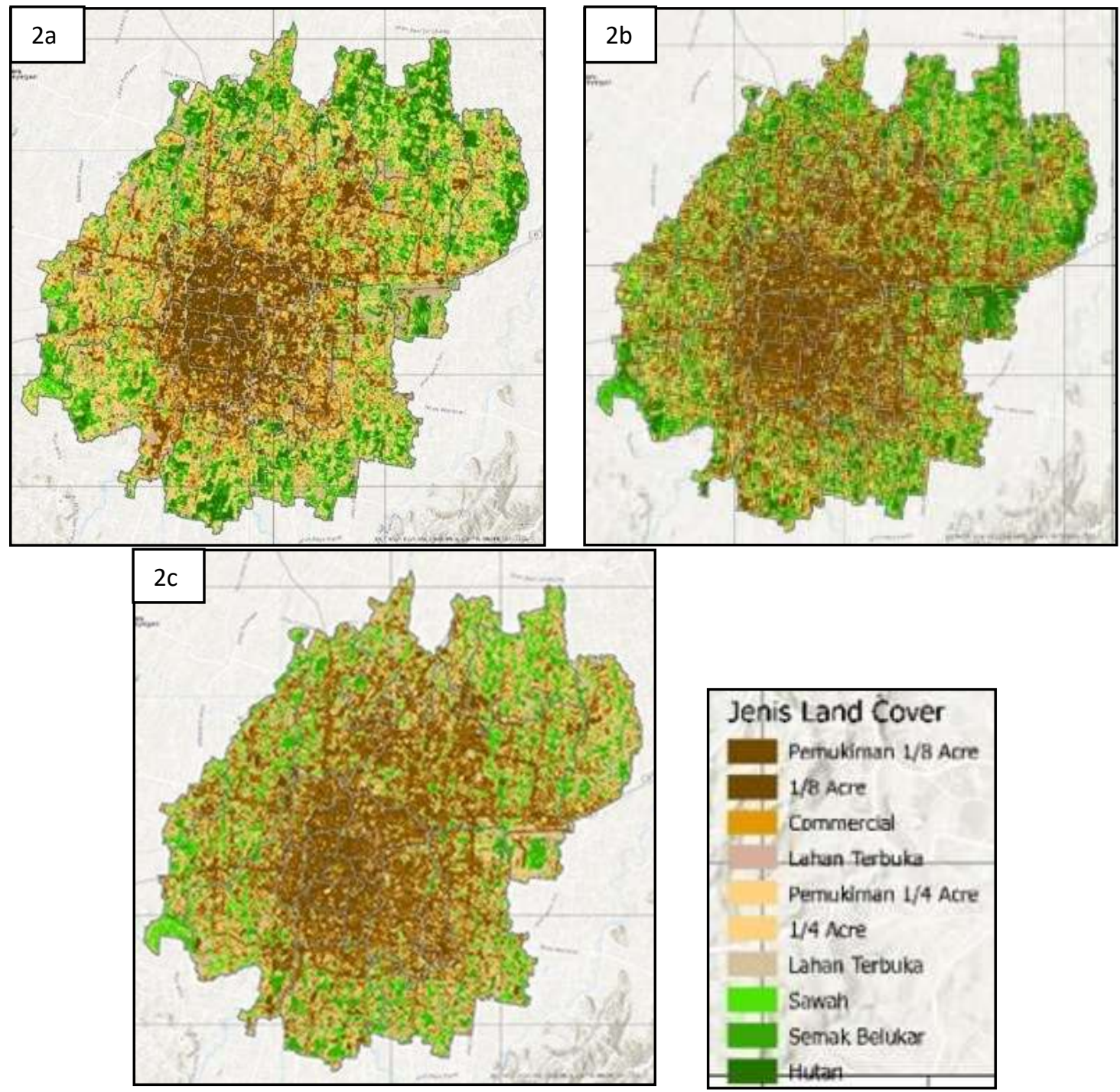

Gambar 2. (a) Penggunaan Lahan Tahun 2008; (b) Penggunaan Lahan Tahun 2013;

(c) Penggunaan Lahan Tahun 2018

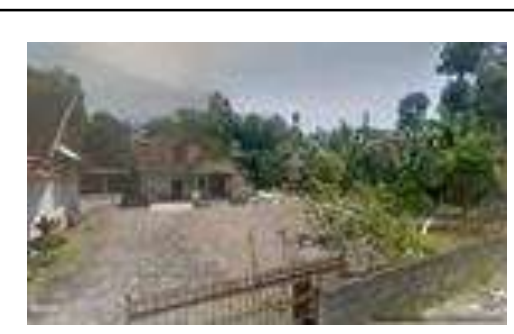

(a)

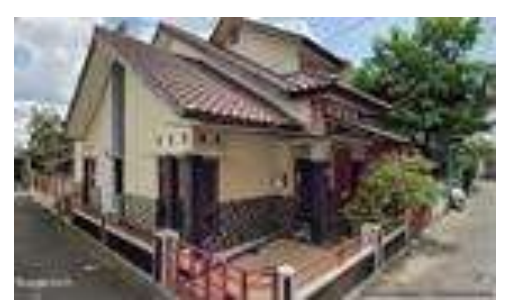

(b)

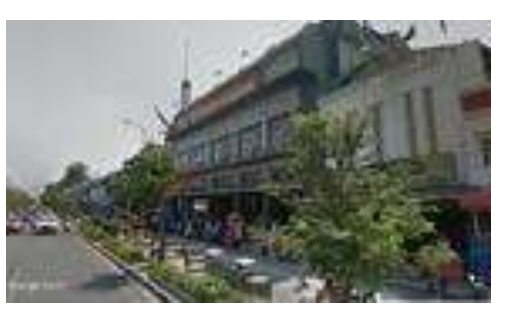

(c)

Gambar 3. (a) Bangunan Pemukiman 1/4 Acre (0,1 ha); (b) Bangunan Pemukiman 1/8 Acre $(0,05 \mathrm{ha}) ;$ (c) Bangunan Commercial

Pemukiman $1 / 8$ acre memiliki ukuran tanah $\leq 0,05$ ha (Gambar $3 b$ ). Pemukiman dapat berupa sebuah rumah dengan minim halaman atau tidak memiliki halaman dengan ukuran tersebut (Town House). Pemukiman 1/4 acre (Gambar 3a) memiliki ukuran tanah $\pm 0,1$ ha dan memiliki halaman 
yang cukup luas atau setidaknya terdapat halaman. Area komersil memiliki ukuran yang bervariasi, namun dicirikan dengan bangunan berdempet minim area terbuka dan/atau terdapat tutupan semen atau paving block untuk area parkir/untuk pedestrian (Gambar 3c). Perubahan penggunaan lahan terdapat pada lahan vegetasi sawah di area sub-urban (Gambar 2a dan 2b), lahan sawah mengalami penurunan dan mulai menghilang di tahun 2018 (Gambar 2c). Area sawah berubah menjadi lahan terbangun seperti pemukiman, komersial, atau lahan terbuka. Bentuk pola lahan terbangun memusat pada pusat kota. Pertumbuhan lahan terbangun terlihat mengarah ke wilayah Kabupaten Sleman tepatnya di Kecamatan Depok dan Ngaglik.

Nilai luasan penggunaan lahan menunjukkan perbedaan yang tidak terlalu signifikan (Tabel 2), sehingga dilakukan penyederhanaan karena hasil klasifikasi penggunaan lahan hanya menggunakan interpretasi citra dengan resolusi rendah (Tabel 3 dan Gambar 4). Lahan terbangun setiap tahun semakin meningkat disertai dengan lahan vegetasi yang menurun. Hal ini sesuai dengan penurunan vegetasi berupa lahan sawah pada area pinggiran kota yaitu area Bantul (Kecamatan Banguntapan, Sewon, Kasihan,) dan Sleman (Kecamatan Gamping, Mlati, Ngaglik, Depok, Ngemplak). Luas penggunaan lahan tertinggi yaitu lahan terbangun dengan luasan 14.059,5 ha (tahun 2018) dan terendah yaitu lahan terbuka dengan luasan 400,8 ha (tahun 2013). Hal ini serupa dengan peningkatan pemukiman dengan luasan tanah 1/8 acre $(0,05 \mathrm{ha})$ pada area pinggiran kota yang memusat ke pusat kota dan juga berupa konversi lahan vegetasi menjadi pemukiman.

Tabel 2. Rekapitulasi Luas Penggunaan Lahan Berdasarkan Jenisnya di KPY Tahun $2008-2018$

\begin{tabular}{lcrr}
\hline \multicolumn{1}{c}{ Jenis Land Cover } & & Luas (Ha) & \multicolumn{1}{c}{2018} \\
\hline Commercial & 2008 & 2013 & $4.241,4$ \\
Hutan & $2.701,9$ & $4.665,3$ & $1.562,7$ \\
Lahan Terbuka & $1.236,8$ & $1.482,7$ & $1.466,2$ \\
Pem. 1/4 Acre & $1.913,2$ & 400,8 & $5.381,1$ \\
Pem. 1/8 Acre & $5.039,8$ & $3.881,1$ & $4.437,1$ \\
Sawah & $4.013,9$ & $4.603,2$ & 0 \\
Semak Belukar & $2.666,8$ & $2.256,5$ & $2.568,2$ \\
\hline
\end{tabular}

Tabel 3. Luas Penggunaan Lahan Berdasarkan Jenisnya di KPY Tahun 2008-2018

\begin{tabular}{lrrr}
\hline \multicolumn{1}{c}{ Jenis Land Cover } & \multicolumn{3}{c}{ Luas $(\mathrm{Ha})$} \\
& 2008 & 2013 & \multicolumn{1}{c}{2018} \\
\hline Lahan Terbangun & $11.755,6$ & $13.149,5$ & $14.059,5$ \\
Lahan Terbuka & $1.913,2$ & 400,8 & $1.466,2$ \\
Vegetasi & $5.987,6$ & $6.106,8$ & $4.130,9$ \\
\hline
\end{tabular}




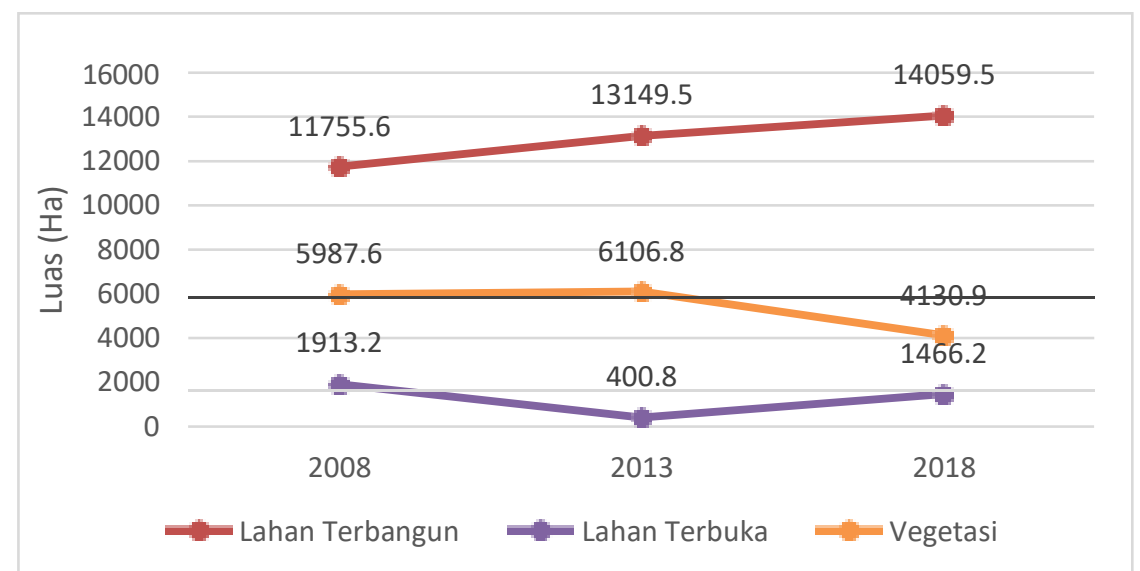

Gambar 4. Perubahan Luas Penggunaan Lahan di KPY Tahun 2008 - 2018

\section{Distribusi Spasial Temporal Runoff di Kawasan Perkotaan Yogyakarta}

Terdapat fluktuasi volume runoff maksimum di Kawasan Perkotaan Yogyakarta, terdapat peningkatan dan penurunan volume runoff pada beberapa stasiun hujan. Area stasiun hujan Gemawang memiliki peningkatan volume runoff yang cukup signifikan dan nilai volume tertinggi pada lahan terbangun dibandingkan dengan stasiun lainnya (Tabel 4). Hal tersebut juga terlihat dari semakin gelapnya area stasiun Gemawang (Gambar 5). Area stasiun hujan Bedukan mengalami peningkatan secara keseluruhan, terdapat perbedaan warna yang semakin gelap dari tahun 2013 ke 2018 (Gambar 5b dan 5c). Stasiun hujan Plataran juga mengalami peningkatan, terutama pada lahan terbangun yang meningkat pesat dari tahun 2013 ke 2018 (Gambar 5b dan 5c). Adanya peningkatan volume runoff pada stasiun Gemawang, Plataran dan Bedukan sesuai dengan peningkatan perubahan penggunaan lahan yang terkonsentrasi di area utara atau Kabupaten Sleman, teurtama pada area sub-urban Kota Yogyakarta.
Terdapat juga area yang mengalami penurunan volume runoff yaitu pada area stasiun hujan Pajangan (Tabel 4). Area stasiun hujan Nyemengan, Tanjung Tirto, Santan, Beran dan Prumpung mengalami fluktasi nilai volume tiap tahunnya (Tabel 4). Penurunan tersebut mengakibatkan perubahan pada area selatan dan timur serta meningkat pada kawasan utara Kawasan Perkotaan Yogyakarta meliputi Kecamatan Mlati, Kalasan, Ngaglik, Depok, dan Ngemplak. Selain itu, penurunan volume runoff dipengaruhi oleh meningkatnya kawasan lahan terbuka pada tahun 2018 dan menurunnya lahan vegetasi (Gambar 4). Hal tersebut menyebabkan mudahnya infiltrasi dan mengurangi volume runoff. Sebagian besar sebaran spasial dengan area paling gelap berada di Kota Yogyakarta. Pada peta penggunaan lahan (Gambar 2a), terlihat bahwa kawasan tersebut merupakan pemukiman $1 / 8$ acre $(0,05$ ha) /kurang atau lahan terbangun. Area cakupan stasiun Tanjung Tirto memiliki volume runoff terendah jika dibandingkan dengan stasiun hujan lainnya (Tabel 4). Hal ini sesuai dengan 
penggunaan lahan pada area tersebut (Gambar 2a) masih terdapat banyak vegetasi terutama lahan sawah, dan semak belukar.

Tabel 4. Volume Runoff Max pada setiap stasiun hujan

\begin{tabular}{|c|c|c|c|c|}
\hline \multirow{2}{*}{ Nama Stasiun } & \multirow{2}{*}{ Tahun } & \multicolumn{3}{|c|}{ Volume Runoff } \\
\hline & & Lahan Terbangun & Lahan Terbuka & Vegetasi \\
\hline \multirow{3}{*}{ Bedukan } & 2008 & 551,84 & 131,17 & 358,95 \\
\hline & 2013 & $1.070,86$ & 37,17 & 541,17 \\
\hline & 2018 & $2.394,22$ & 320,12 & 740,84 \\
\hline \multirow{3}{*}{ Beran } & 2008 & 167,56 & 39,67 & 318,98 \\
\hline & 2013 & 142,25 & 7,53 & 178,79 \\
\hline & 2018 & 235,46 & 87,73 & 189,59 \\
\hline \multirow{3}{*}{ Gemawang } & 2008 & $2.397,48$ & 275,88 & 470,93 \\
\hline & 2013 & $4.352,49$ & 125,35 & 897,92 \\
\hline & 2018 & $4.584,18$ & 200,74 & 615,89 \\
\hline \multirow{3}{*}{ Godean } & 2008 & 143,38 & 23,01 & 58,42 \\
\hline & 2013 & 184,44 & 2,35 & 90,61 \\
\hline & 2018 & 121,34 & 13,57 & 39,89 \\
\hline \multirow{3}{*}{ Karang Ploso } & 2008 & 101,83 & 23,29 & 83,54 \\
\hline & 2013 & 188,51 & 5,61 & 118,62 \\
\hline & 2018 & 242,96 & 32,28 & 102,98 \\
\hline \multirow{3}{*}{ Nyemengan } & 2008 & $2.060,81$ & 289,04 & 819,25 \\
\hline & 2013 & $2.886,86$ & 84,01 & 905,11 \\
\hline & 2018 & $1.849,73$ & 142,99 & 366,65 \\
\hline \multirow{3}{*}{ Pajangan } & 2008 & 51,73 & 10,81 & 91,71 \\
\hline & 2013 & 44,94 & 1,64 & 105,56 \\
\hline & 2018 & 41,96 & 14,56 & 48,96 \\
\hline \multirow{3}{*}{ Plataran } & 2008 & 158,28 & 30,76 & 201,57 \\
\hline & 2013 & 205,24 & 6,71 & 223,02 \\
\hline & 2018 & 493,20 & 109,34 & 253,25 \\
\hline \multirow{3}{*}{ Prumpung } & 2008 & 278,28 & 36,72 & 322,91 \\
\hline & 2013 & 742,01 & 13,53 & 684,24 \\
\hline & 2018 & 729,60 & 157,11 & 297,17 \\
\hline \multirow{3}{*}{ Santan } & 2008 & $1.322,96$ & 286,26 & 538,04 \\
\hline & 2013 & $2.402,61$ & 75,00 & 934,25 \\
\hline & 2018 & 1919,58 & 214,40 & 402,14 \\
\hline \multirow{3}{*}{ Tanjung Tirto } & 2008 & 34,54 & 10,83 & 69,98 \\
\hline & 2013 & 138,96 & 9,75 & 240,88 \\
\hline & 2018 & 225,41 & 98,16 & 115,29 \\
\hline
\end{tabular}
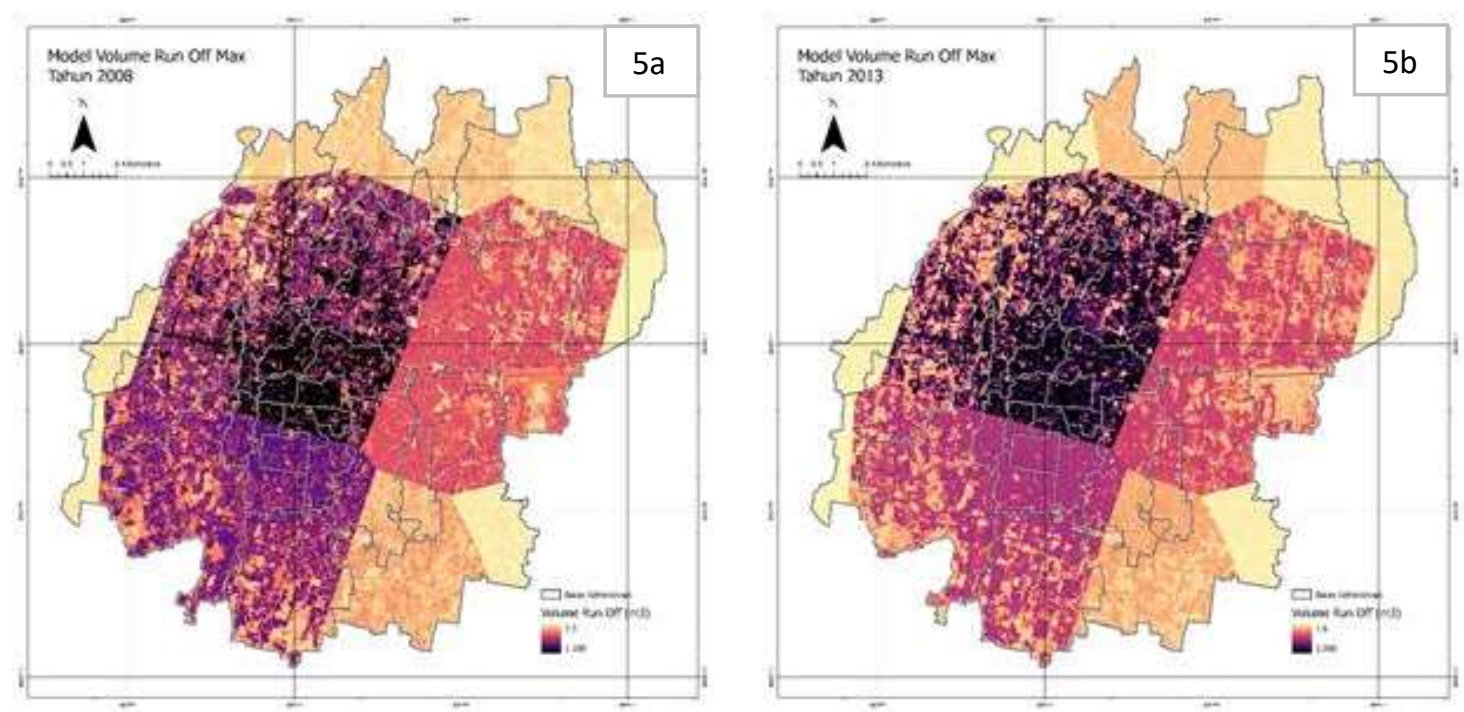

240 | Media Komunikasi Geografi, Vol. 22, No. 2, Desember 2021: 231-246 


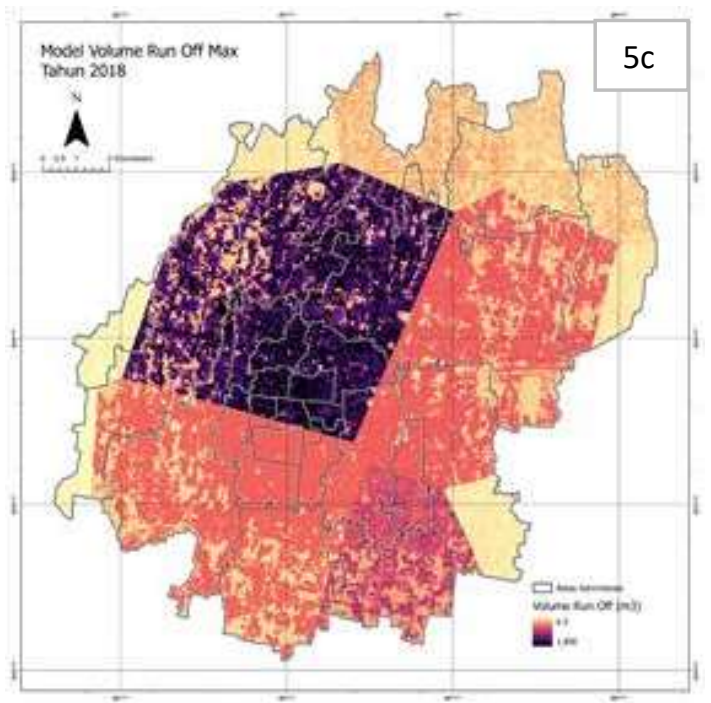

Gambar 5. (a) Peta Curah Hujan Rata - Rata Maksimum Tahun 2008; (b) Peta Curah Hujan Rata - Rata Maksimum Tahun 2013; (c) Peta Curah Hujan Rata - Rata Maksimum Tahun 2018

Pada Tabel 5 dan Gambar 6 terlihat bahwa terdapat peningkatan volume runoff pada lahan terbangun dari tahun ke tahun dan puncaknya berada pada tahun 2018. Selain itu, terdapat penurunan pada lahan terbuka dari tahun 2008 ke 2013 hal ini diakibatkan oleh adanya pengalihan lahan ke lahan terbangun atau area tersebut ditumbuhi vegetasi yang dapat terlihat pada peningkatan lahan vegetasi tahun 2008 ke 2013. Lahan terbuka mengalami sedikit peningkatan pada tahun 2018 begitu adanya peningkatan vegetasi pada tahun 2018 hal ini dapat saling berhubungan dikarenakan vegetasi mulai menghilang atau kering. Penurunan vegetasi di tahun 2018 juga dapat dikarenakan adanya peningkatan lahan terbangun di tahun 2018 . Secara keseluruhan hal ini sesuai dengan persebaran spasial volume runoff pada Gambar 5. Peningkatan lahan terbangun terlihat pada area stasiun Gemawang. Penurunan lahan terbuka pada tahun 2008 ke 2013 juga merupakan akibat dari peningkatan lahan terbangun di area stasiun Gemawang. Peningkatan lahan terbuka dan menurunnya lahan vegetasi pada tahun 2018

mempermudah laju infiltrasi sehingga terdapat penurunan volume runoff pada area stasiun hujan seperti Beran, Pajangan, Nyemengan dan Santan. Selain itu, fluktuasi curah hujan bulanan dari tahun ke tahun juga mempengaruhi volume runoff.

Tabel 5. Volume Runoff Terhadap Penggunaan Lahan Tahun 2008, 2013, dan 2018

\begin{tabular}{rrrr}
\hline Tahun & \multicolumn{3}{c}{ Volume Runoff $\left(\mathrm{m}^{3}\right)$} \\
& Lahan Terbuka & Vegetasi \\
\hline 2008 & $7.268,68$ & $1.157,44$ & $3.233,92$ \\
2013 & $12.359,15$ & 368,65 & $4.920,18$ \\
2018 & $12.837,63$ & $1.390,98$ & $3.172,66$ \\
\hline
\end{tabular}




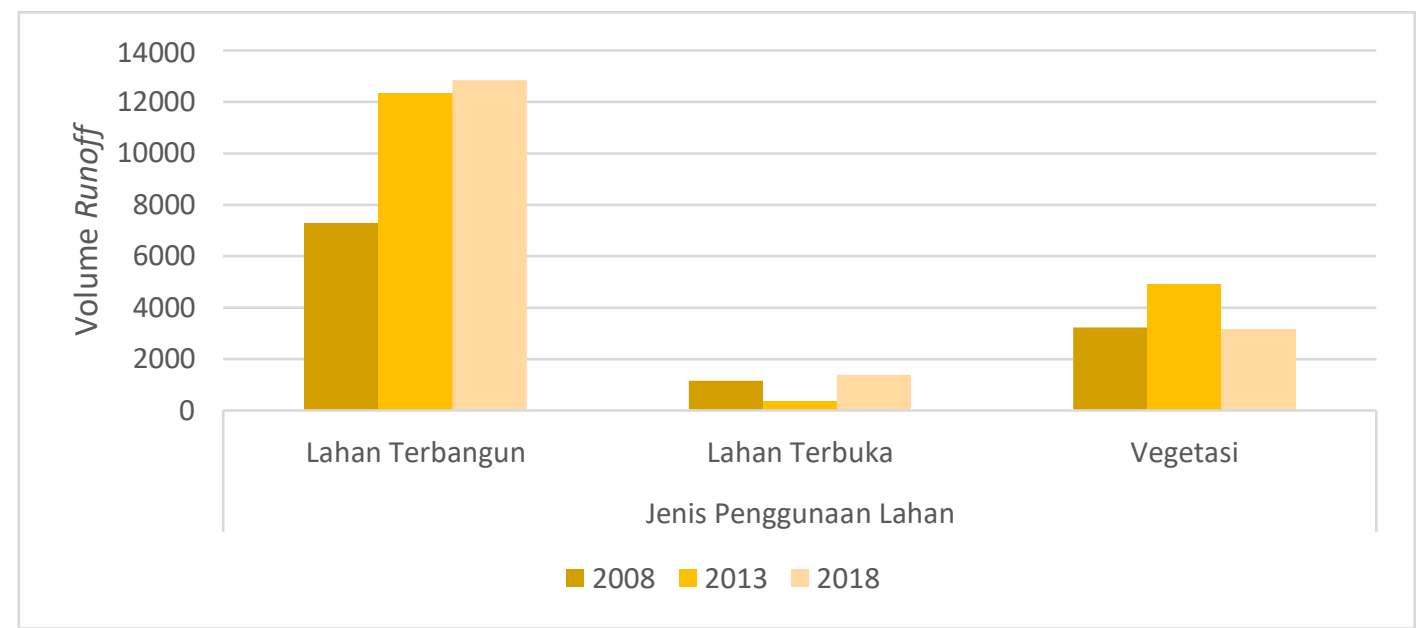

Gambar 6. GrafikVolume Runoff Terhadap Penggunaan Lahan Tahun 2008, 2013, dan 2018

\section{Hubungan Penggunaan Lahan Terhadap Volume Runoff di Kawasan Perkotaan Yogyakarta}

Penggunaan lahan memiliki peran besar terhadap volume runoff pada Kawasan Perkotaan Yogyakarta. Semakin banyak lahan terbangun maka semakin minim infiltrasi yang dapat dilakukan oleh tanah karena terhalang oleh bangunan. Perhitungan korelasi penggunaan lahan terhadap volume run off diperlukan untuk mengetahui seberapa kuat hubungan kedua parameter tersebut. Perhitungan korelasi ini menggunakan metode Pearson.

Pada Tabel 6 terlihat bahwa nilai koefisien determinasi lahan terbangun, lahan terbuka, dan vegetasi mendekati 1 yang menandakan bahwa ada korelasi antara penggunaan lahan dan volume runoff. Nilai $R^{2}$ juga mendekati 1 dan titik korelasi tersebut hampir linear dengan trendline (Gambar 7, 8, dan 9). Hal tersebut menunjukkan adanya nilai yang signifikan. Korelasi $Y$ menunjukkan bahwa jika lahan terbangun bertambah
100 ha maka akan ada kenaikan volume run off sebanyak 76,09 $\mathrm{m}^{3}$. Korelasi $Y$ untuk lahan terbuka jika bertambah 100 ha maka akan ada kenaikan volume run off sebanyak $59,27 \mathrm{~m}^{3}$. Sementara untuk lahan vegetas, jika setiap luas lahan vegetasi bertambah 100 ha, volume run off akan bertambah $54 \mathrm{~m}^{3}$. Hal tersebut memperlihatkan bahwa kenaikan volume runoff tertinggi berada pada lahan terbangun dan terendah pada lahan vegetasi. Selain itu, pada korelasi Pearson, $\mathrm{p}$ - value memiliki nilai yang signifikan dan berkorelasi secara statistik karena $p$-value dibawah 0,05 dan t-hitung lebih besar dari t-tabel. Hasil tersebut menunjukkan bahwa adanya hubungan antara kenaikan volume runoff terhadap bertambahnya penggunaan lahan terutama pada lahan terbangun. Hal tersebut menyebabkan adanya potensi banjir yang semakin tinggi di Kawasan Perkotaan Yogyakarta, terutama pada lokasi dengan volume runoff tertinggi yaitu di kawasan stasiun hujan Gemawang yang meliputi sebagian 
Kecamatan Mlati, Gamping, Kasihan, Depok, Gondokusuman, Mergangsan, Ngambilan, Gondomanan, Umbulharjo,
Ngaglik, dan Ngemplak serta seluruh Kecamatan Danurejan, Pakualaman, Jetis, Gedongtengen, dan Tegalrejo.

Tabel 6. Korelasi Pearson antara Penggunaan Lahan dan Volume Runoff

\begin{tabular}{|c|c|}
\hline Jenis Penggunaan Lahan & Korelasi \\
\hline Lahan Terbangun & 0,92 \\
\hline Lahan Terbuka & 0,88 \\
\hline Vegetasi & 0,75 \\
\hline
\end{tabular}

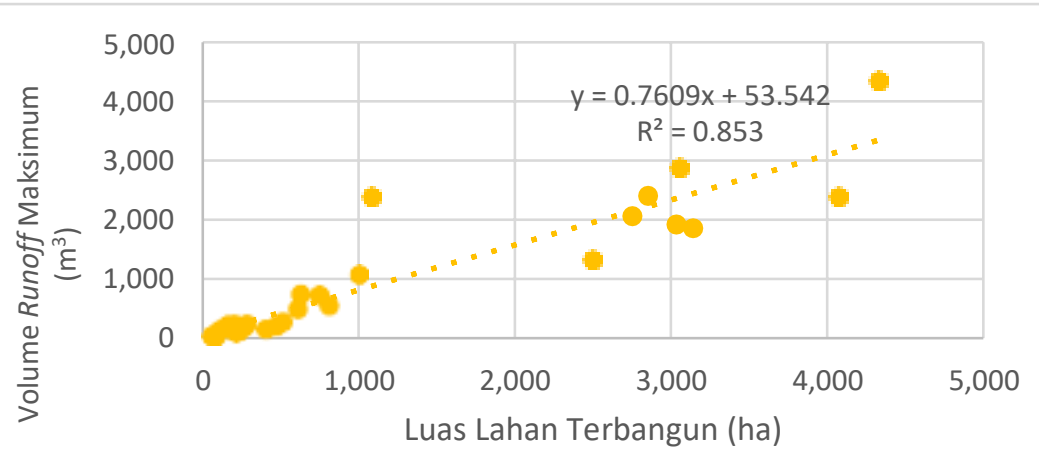

Gambar 7. Korelasi Luas Lahan Terbangun Terhadap Volume Runoff

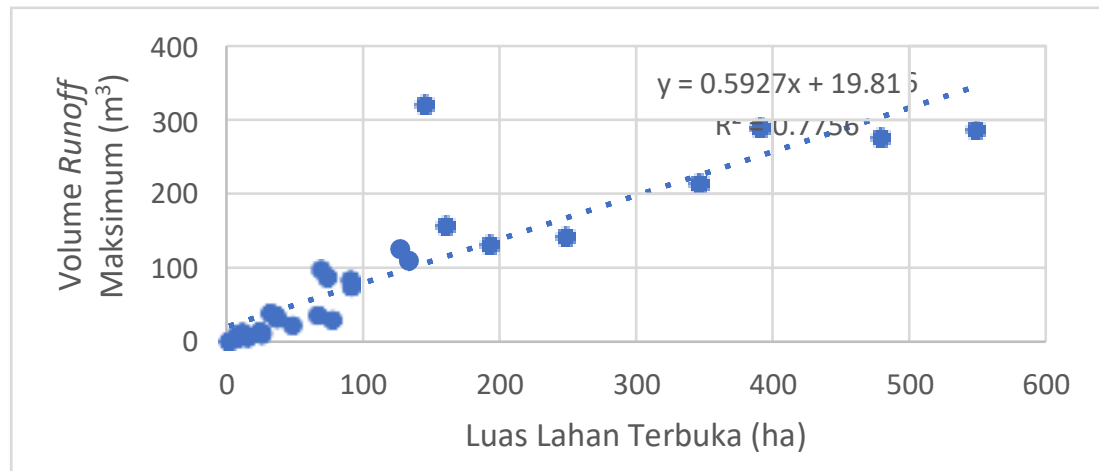

Gambar 8. Korelasi Luas Lahan Terbuka Terhadap Volume Runoff

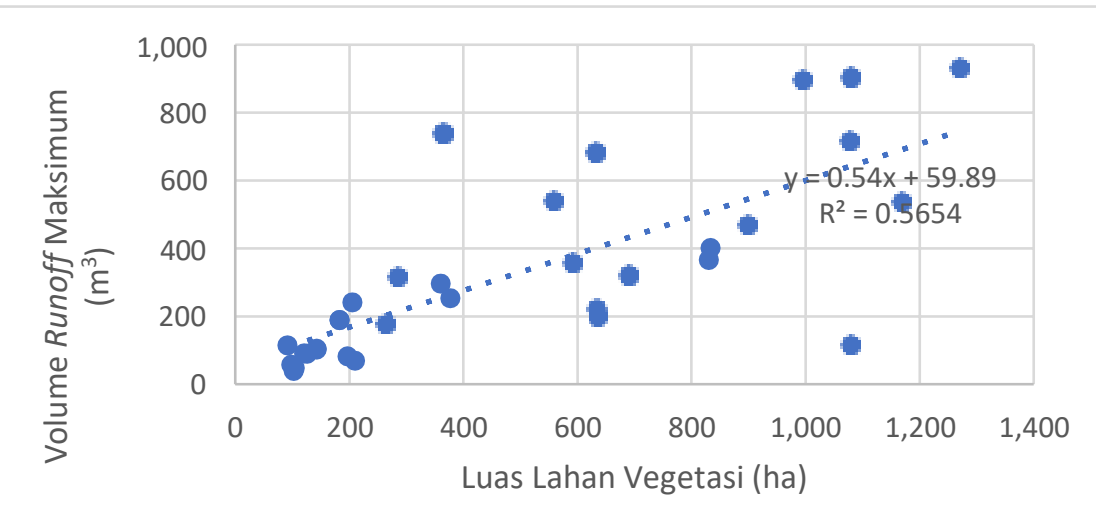

Gambar 9. Korelasi Luas Lahan Vegetasi Terhadap Runoff

243 | Media Komunikasi Geografi, Vol. 22, No. 2, Desember 2021: 231-246 
Tabel 7. Hasil Uji Statistik

\begin{tabular}{lr}
\hline \multicolumn{1}{c}{ Jenis Penggunaan Lahan } & Nilai T \\
\hline Lahan Terbangun & 13,41 \\
Lahan Terbuka & 10,35 \\
Vegetasi & 6,35 \\
\hline
\end{tabular}

Tabel 8. P-Value

\begin{tabular}{lr}
\hline \multicolumn{1}{c}{ Jenis Penggunaan Lahan } & P-Value \\
\hline Lahan Terbangun & 0.0000000000000189 \\
Lahan Terbuka & 0.0000000000139 \\
Vegetasi & 0.000000454 \\
\hline
\end{tabular}

Peningkatan luasan lahan terbangun menjadi salah satu faktor pemicu kenaikan volume runoff (Sun et al., 2014). Selama kurun waktu 2008 hinga 2018 di Kawasan Perkotaan Yogyakarta telah terjadi peningkatan volume runoff sebesar $49 \%$. Penelitian sebelumnya yang dilakukan di DAS Bedog menunjukkan bahwa perubahan penggunaan lahan menjadi permukiman sebesar $0,4 \%$ per tahun memicu perubahan tebal runoff sebesar $2 \%$ (Yudha \& Dibyosaputro, 2016). Namun, kontribusi perubahan penggunaan lahan terhadap perubahan volume runoff bervariasi di setiap lokasi di permukaan bumi. Laju perubahan iklim menyumbang $87,15 \%$ terhadap perubahan runoff di Heihe River Basin China, sedangkan penggunaan lahan hanya berkontribusi $12,85 \%$ (Shang et al., 2019)

$$
\text { Identifikasi spasiotemporal }
$$

perubahan penggunaan lahan dan perubahan volume runoff dapat memberikan gambaran mengenai pola pembangunan di suatu perkotaan (Ansari et al., 2016; Atharinafi \& Wijaya, 2021). Hasil kajian ini dapat dimanfaatkan dalam perencanaan perkotaan maupun manajemen bencana perkotaan khususnya bencana banjir. Beberapa strategi yang dapat dilakukan yaitu strategi untuk meminimalisir bahaya, meminimalisir kerentanan terhadap kerusakan dan melestarikan sistem lingkungan alami dataran banjir. Strategi dalam meminimalisir bahaya dapat dilakukan dengan beberapa tindakan seperti manajemen daerah tangkapan dan menyimpan kebutuhan spasial untuk tindakan struktural. Sementara untuk meminimalisir kerentanan terhadap kerusakan dapat dilakukan tindakan dengan mengontrol pembangunan terhadap dataran banjir, mengatur lokasi fasilitas, adanya building code (standar untuk keamanan bangunan yang di rancang oleh pemerintah), dan pemeriksaan banjir. Lalu dengan strategi melestarikan sistem lingkungan dataran banjir dapat dilakukan tindakan berupa menyeimbangkan kebutuhan pembangunan (Mustafa et al., 2015).

\section{Penutup}

Selama kurun waktu 2008 2018, luas penggunaan lahan terbangun meningkat sebanyak $19,5 \%$ dari $11.755,6$ ha pada tahun 2008 menjadi 14.059,5 ha pada tahun 2018 . Distribusi spasial temporal volume runoff di Kawasan Perkotaan Yogyakarta mengalami fluktuasi dari tahun ke tahun. Stasiun hujan Gemawang, Plataran dan Bedukan mengalami peningkatan volume setiap 
tahunnya, sesuai dengan peningkatan perubahan penggunaan lahan. Stasiun Pajangan mengalami penurunan dan sementara stasiun hujan Nyemengan, Beran, Tanjung Tirto, Santan dan Prumpung mengalami fluktuasi. Selama kurun waktu 2008 - 2018 volume runoff mengalami kenaikan sebanyak $76,6 \%$ dari $7.268,68 \mathrm{~m}^{3}$ pada tahun 2008 menjadi 12.837,63 m3 pada tahun 2018. Penggunaan lahan dan volume runoff menmiliki korelasi signifikan secara statistik dilihat dari nilai persen korelasi dibawah 5\%. Hasil korelasi Pearson menunjukkan nilai tertinggi berada pada volume runoff dengan luas lahan terbangun.

Kekurangan dalam penelitian ini berkaitan dengan terbatasnya ketersediaan data hujan di wilayah penelitian dan tingkat kedetailan klasifikasi tutupan lahan. Pengembangan untuk penelitian selanjutnya dapat menggunakan data hujan dari hasil pemodelan dan menggunakan citra resolusi tinggi untuk klasifikasi tutupan lahan. Selanjutnya penelitian mengenai prediksi perubahan penggunaan lahan serta kenaikan volume runoff di masa depan penting untuk dilakukan dalam rangka pengurangan risiko bencana banjir perkotaan.

\section{Daftar Pustaka}

Ansari, T. A., Katpatal, Y. B., \& Vasudeo, A. D. (2016). Spatial evaluation of impacts of increase in impervious surface area on SCS-CN and runoff in Nagpur urban watersheds, India. Arabian Journal of Geosciences, 9(18). https://doi.org/10.1007/s12517016-2702-5
Atharinafi, Z., \& Wijaya, N. (2021). Land use change and its impacts on surface runoff in rural areas of the upper citarum watershed (case study: Cirasea subwatershed). Journal of Regional and City Planning, 32(1), 36-55. https://doi.org/10.5614/jpwk.2021. 32.1 .3

Chadchan, J., \& Shankar, R. (2009). Emerging Urban Development Issues in the Context of Globalization. Institute of Town Planner, India Journal, 6 (2)(AprilJune), 78-85. http://www.itpi.org.in/pdfs/apr6_09. pdf

He, Y., Lin, K., \& Chen, X. (2013). Effect of land use and climate change on runoff in the Dongjiang basin of south China. Mathematical Problems in Engineering, 2013. https://doi.org/10.1155/2013/47142 9

Hu, S., Fan, Y., \& Zhang, T. (2020). Assessing the $\mathrm{E} f \mathrm{ff}$ ect of Land Use Change on Surface Runo ff in a Rapidly Urbanized City: A Case Study of. Land, 9(17), 1-15.

Liu, J. D. (2005). China's environment in a globalizing world. Nature, 435(June), 1179-1186.

Mishra, S. K., Chaudhary, A., \& Shrestha, R. K. (2014). Experimental Verification of the Effect of Slope and Land Use on SCS Runoff Curve Number. Knisel 1980.

https://doi.org/10.1007/s11269014-0582-6

Mustafa, A., Dewals, B., Archambeau, P., Pirotton, M., \& Teller, J. (2015). Sustainable integrated land-use plan and flood risk management: A review. Doctoral Seminar on Sustainability Research in the Built Environment (DS2BE-2015), October 2020. 
Patra, S., Sahoo, S., Mishra, P., \& Mahapatra, S. C. (2018). Impacts of urbanization on land use /cover changes and its probable implications on local climate and groundwater level. Journal of Urban Management, 7(2), 70-84. https://doi.org/10.1016/j.jum.2018. 04.006

Psomiadis, E., Soulis, K. X., \& Efthimiou, N. (2020). Using SCS$\mathrm{CN}$ and earth observation for the comparative assessment of the hydrological effect of gradual and abrupt spatiotemporal land cover changes. Water (Switzerland), 12(5).

https://doi.org/10.3390/W1205138 6

Sajikumar, N., \& Remya, R. S. (2015). Impact of land cover and land use change on runoff characteristics. Journal of Environmental Management, 161, 460-468. https://doi.org/10.1016/j.jenvman.2 014.12 .041

Shang, X., Jiang, X., Jia, R., \& Wei, C. (2019). Land use and climate change effects on surface runoff variations in the upper Heihe River basin. Water (Switzerland), 11(2). https://doi.org/10.3390/w11020344

Sugiyono. (2006). Statistika untuk Penelitian. CV. Alfabeta.

Sun, Z., Li, X., Fu, W., Li, Y., \& Tang, D. (2014). Long-term effects of land use/land cover change on surface runoff in urban areas of Beijing, China. Journal of Applied Remote Sensing, 8. https://doi.org/10.1117/1

Triatmojo, B. (2010). Hidrologi Teknik Terapan. Beta Offset.

United Nations Department of Economic and Social Affairs. (2015). World Urbanization Prospects: The 2014 Revision.
United States Department of Agriculture. (1986). Urban Hydrology for Small Watershed. Soil Conservation, Technical Release 55 (TR-55), 164.

http://scholar.google.com/scholar? $\mathrm{hl}=\mathrm{en} \& b \operatorname{bn} \mathrm{G}=$ Search \&q=intitle:Urb an+Hydrology+for+Small+watersh eds\#1

Wilonoyudho, S., Rijanta, R., Keban, Y. T., \& Setiawan, B. (2017). Urbanization and regional imbalances in Indonesia. Indonesian Journal of Geography, 49(2), 125-132. https://doi.org/10.22146/ijg.13039

Yudha, S., \& Dibyosaputro, S. (2016). Dampak Perubahan Penggunaan Lahan terhadap Perubahan Runoff di Daerah Aliran Sungai (DAS) Bedog Yogyakarta. Majalah Geografi Indonesia, 27(2), 117137. https://doi.org/10.22146/mgi.13426 Zhou, B., Rybski, D., \& Kropp, J. P. (2017). The role of city size and urban form in the surface urban heat island. Scientific Reports, $7(1)$, $1-9$. https://doi.org/10.1038/s41598017-04242-2 